"when I ask with what important achievement in philosophy or in natural science, or with what permanent contribution to thought his name is destined to be connected, I meet with no satisfactory reply'. At face value, this seems to be alarmingly close to the Medawars' view of Aristotle!

Experienced Medawar readers will recognize that a good deal of the serious matter of the dictionary represents Sir Peter's scientific preoccupations of many years standing - demography, growth and form, the immune system and so on. These little essays are beautifully written, trenchant, witty and informative. They are also so erratic in level as to provoke me into articulating the question I had vowed, before writing this review, not to ask. For whom are these essays written? For example, "Growth, Laws of Biological" has a full-page table giving the equations and analytical properties of three growth functions, while "Population, Growth and Control" has a little box showing what an exponential series is. It probably doesn't matter. After all if some of the subject matter of biology lends itself to elegant mathematical treatment, then why should not the numerate man in the street be given the pleasure of enjoying it?

In the same context, an odd feature of the book is the evidence that its authors do not have a particularly high regard for the intellectual pretensions of the very members of the lay public who must be expected to buy it in largest numbers. Twice this group is identified as that to which the structural formula of water represents the upper limit of scientific knowledge. I do not trust this attitude. Who knows how the lay public, deprived of precise understanding, perceives science? What is certain is that it does not want to have its head bitten off by the Medawars because it knows only that $\mathrm{H}_{2} \mathrm{O}$ is water, or because it does not yet know that man is not an aggressive animal, or that you can't change human nature. It does not help to be told merely that "educated people do not have to refer to ethological papers before rebutting these trite propositions. Indeed, such phrases are now almost universally taken to mark an especially low level in conversation or discussion". I can only suppose that these strictures are intended to frighten the ignoramus into silence.

But it is best not to worry, and rather enjoy the lovely prose and the tough precise intelligence. This is not the place to hunt for oncogenes, homeotic mutants or other heroic manifestations of the trend end of modern molecular biology. Rather, Aristotle to Zoos is more like a guided tour through an antiquary's collection of unusual, funny, embarrassing or lovely things chosen for their intrinsic interest or on a whim rather than for topicality or information alone. In Voltaire's Dictionary the whimsical titles and strange oblique manner were the disguises of a robust and effective attack on the hypocrisy, intellectual poverty and temporal tyranny of the Catholic Church. If a central informing theme is to be found in the Medawars' dictionary, it is an appeal for a disciplined and critical mind.

A final comment, suggested appropriately by the essay on zoos. Experimental biologists are often called on to abuse animals in the course of their work. These abuses are both sanctioned and limited by the laws which cover cruelty to animals. It is important to realize that, in Britain, the Cruelty to Animals Act (1876) is explicitly intended to permit cruelty to animals. Without a doubt, this licensed cruelty to animals takes its toll on the scientist's sensibilities, on his ability to judge the consequences of his experiment by what one might call "normal" humane standards. Just because our animal experimentation is regulated by law, and law which is necessarily diffuse and imprecise in application, it is difficult for the scientist to retain a sense of primary obligation to the animal rather than to the law or to the experiment. Both in "Zoos", and more explicitly in the superbly judged and eloquent essay "Animals and Human Obligations", the Medawars show that they have managed, after a lifetime in experimental biology, to keep their sensibilities intact.

Jonathan C. Howard is at the Agricultural Research Council's Institute for Animal Physiology, Babraham, Cambridge.

\section{Thoughts from the High Table}

\section{Steven Rose}

The Synergism Hypothesis: A Theory of Progressive Evolution.

By Peter A. Corning.

Blond \& Briggs/McGraw-Hill: 1983.

Pp.492. Hbk £15, \$19.95;

pbk \$12.95.

CONFRONTING the ultimate question, the secret of life, the universe and everything, that well-known text $A$ Hitchhiker's Guide to the Galaxy responds simply " 42 ". Dr Corning's response is The Synergism Hypothesis but, unlike the Guide, he takes a full 492 pages of eclectic and autodidactic argument to expound a thesis which he claims embraces everything from biological evolution to how to run hospitals in California, taking in en route cost-benefit analyses of the relative merits of the political systems of Iran and Mexico, and cooperative phenomena in the synthesis of proteins. It is at once evident that in The Synergism Hypothesis we are confronted with a book that its author and publishers wish us to see as a Great Event. Faced with such a range of subject matter and an author who we are told is "one of the pioneers in applying a biological perspective to the social sciences" how is a poor Cambridge empiricist like the present reviewer, constrained to crawling along the frontiers of knowledge with a hand-lens, and taught to eschew Grand Theory, to cope?

Dr Corning, as we might imagine, has few doubts as to the importance of what he has achieved - "like Darwin's theory, properly understood, my theory makes only one unequivocal prediction', he informs us with no false modesty (p.392). One's sense of awe is only slightly quenched to read on as follows: "that the future cannot be predicted with certainty because the process is not linear or deterministic ...". Well yes, but Darwin had just a little more to say than that, or we would not still be reading him today. Dr Corning, however, sees himself firmly seated at High Table with the intellectual giants of the past 2,500 years, praising Plato and Durkheim here, criticizing Marx and Darwin there, mapping his own ideological descent with a scent-marking of faint acclaims and sharp disapprovals.

So what is the Synergism Hypothesis? "Functional synergism is so much a part of our daily lives that we generally take it for granted" (p.228). Well, thanks. But is it new? "Plato and Aristotle understood the synergism principle; so did Adam Smith" (p.229). So why do we read Dr Corning? To tell us that we can see synergism at work when we "Imagine a scissors with only one blade, a tweezers with one claw .... a broken drinking glass . . . an electric appli- 
ance during a power outage" (p.230). Synergism is in the food we eat, the baking of a lemon pie, personal health, the telephone system, insurance, shopping centres, multiple movie theatres (p.233). So that's what Adam Smith has in common with a supermarket?

Beneath his grandiose rhetoric and camouflaged by his heavy reference list, Dr Corning is calling attention to the modest but unfortunately not self-evident statement that reductionism is an inadequate programme for the scientific understanding of living organisms or the societies they construct. Although it is not clear why the author thinks he has contributed significantly to the debate over the limits to the reductionist programme, there is no doubt that his book has been written in reaction to claims made even more stridently than his own - those of sociobiology. E.O. Wilson's ludicrous claim that "The development of fundamental theory in sociology must await the full neuronal explanation of the brain" stands, an epigram contrasted with others by Durkheim and Gould, at the head of one major chapter. Dawkins's "lumbering robots" programmed by those misbegotten "selfish genes" lurk wolfishly in Corning's pages to be stripped yet again of their skins to reveal the sheep they really are.

Complex wholes are not reducible to ontologically prior parts; systems have properties which are not dissociable into, or strictly predictable from, the units of which they are composed. New properties emerge with complexity, and genes should no more be described as selfish or aggressive than should humans be regarded as subject to Van der Waal's forces or Brownian motion. Laws of motion descriptive of one level of organization of matter are not translatable, holus-bolus, to another. That these statements are not self-evident is due to the ideological power of reductionism, not least within the pages of Nature. Therefore, I must, in principle, welcome Dr Corning to the side of the good and the true who fight the brave fight against reductionism.

However, mine enemy's enemy is not always to be seen as unequivocally clearheaded and right-minded. In his eagerness to defeat the reductionist myth, Dr Corning elevates synergism itself to the great organizing principle of nature much as Engels once did for the dialectic. Oddly The Dialectics of Nature does not appear to be part of Dr Corning's otherwise omnivorous reading, albeit his list of examples of synergism reads uneasily like Engels's claims to find the transformation of quantity into quality in the boiling of water, and the interpenetration of opposites in the north and south poles of a magnet.

Despite Dr Corning's clarity in avoiding the trap of reducing individual social actions to the mere motions of molecules, he oddly fails to avoid the trap of seeing society as composed of individuals whose market-like relationships conform to some cybernetic principle or other. Whether individuals choose to act socially, he implies, is their own affair - as if they at least were free. Faced with the problems this might entail, he weakly invokes Sperry's principle of downward causation as if this might spring the trap. The consequence is that whilst his early chapters on Darwin, progressive evolution and interactionism are merely platitudinous and longwinded, his final chapter on a "general theory of politics" is downright inadequate. A theory of politics which has no place for conflict - of class, gender or race - and which sees no theoretical difference between socialism and capitalism, is frankly out of place in anything except, apparently, a Stanford Political Science class. It

\section{Between Brussels and Westminster}

\section{Eric Ashby}

EEC Environmental Policy and Britain:

An Essay and a Handbook.

By Nigel Haigh.

Environmental Data Services, Unit 24, Finsbury Business Centre, 40 Bowling Green Lane, London: 1984. Pp.324. Pbk 1 12.95, \$25.

The Pollution Control Policy of the European Communities, 2nd Edn. By Stanley P. Johnson.

Graham \& Trotman, Sterling House, 66 Wilton Road, London: 1983.

Pp.244. £18.

"As BEFITS the genius of Europe, particular attention will be given to intangible values and to protecting the environment. ..". This burst of rhetoric was issued by the heads of state or government in the European Community, when they met in 1972. It is the foundation for an environmental policy for Europe. A weak foundation, in the opinion of some lawyers, for the legal basis of the European Community is the Treaty of Rome; the purpose of the Treaty is to establish free trade between member states. To this end the member states agree to approximate (or "harmonize") their national laws in so far as they "directly affect the establishment or functioning of the common market". Laws to protect the environment are, so these lawyers say, irrelevant to the Treaty unless it can be demonstrated that they "directly" affect trade.

This is no legalistic quibble. An important principle is at stake. Every item of Community law agreed to by a member state involves a corresponding surrender of sovereignty by that state. Directives from the Community, once agreed, have the force of international law. Therefore if Britain acquiesces in some Community law to protect the environment and which has no direct effect on the functioning of the is in this chapter that Dr Corning compares his two Californian hospitals, one cybernetically run, "lean, highly efficient" and generating a satisfactory profit; the second lax, with a "chit-chat culture" which turns a loss to its investors. There is no doubt which Dr Corning prefers. But his account fails to tell us which of these two hospitals has a better patient recovery rate, and in which of the hospitals the patients feel happiest. Could there just be something missing from his Grand Unified Theory?

Steven Rose is Professor of Biology at the Open University. With R. C. Lewontin and L. Kamin, he is author of Not in our Genes to be published later this year by Penguin and Pantheon.

common market, there may be a risk (to quote the words of one of Britain's law lords) of "a creeping surrender of our national sovereignty in almost unlimited fields of law". Well, we have taken the risk.

The Declaration of 1972 has the authority of a moral exhortation and nothing more. It is, for me, a cheering sign of sanity that Britain, though not even a signatory to the 1972 Declaration, has acquiesced - though often with ill grace in many environmental directives from Brussels. The ill grace was not without provocation: the drafting of some of the directives was ham-fisted, not to say stupid; and Britain, having been the first European nation to despoil her environment, has learnt, better than any other European nation, how to repair the damage. So Britain had valuable experience to offer Europe. Has the offer been welcomed? On the whole, no. Nevertheless Britain has accepted the moral, if not legal, obligation to surrender some sovereignty over the control of her own air, water and land. Mr Haigh's book is a critical study of this unrecorded and remarkable influence of the Community on British policy.

If Mr Haigh has a fault, it is an excess of modesty. He calls his volume a "handbook" accompanied by an "essay". It is in fact a penetrating and perceptive analysis of the evolution of an environmental policy for Europe and Britain's response to it; written with scrupulous regard for accuracy and fairness; critical in places but always courteously so; offering opinions of his own which are clearly the result of very careful assessment of a mass of material: a book of outstanding quality. The only justification for calling it a handbook is the systematic way in which the case-studies of over thirty Commission documents are treated; for each one there are the formal particulars, a summary of the content, and an account of how it developed and its effect on practice in the United Kingdom.

In his introductory essay, $\mathrm{Mr}$ Haigh describes the historical and administrative 